DESCRIPTION OF THE DIFFERENT STAGES IN THE LIFE CYCLE OF THE DATE PALM SCALE INSECT, Parlatoria blanchardi TARGIONI TOZZETTI (Homoptera, Diaspididae)

\author{
Abdel Aleem , R.Y. \\ Department of Economic Entomology \& pesticides \\ Fac. Of Agrec., Cairo Univ., Giza, Egypt.
}

ABSTRACT

The different stages of $P$. blanchardi were described. The egg is oblong, whitish yellow and averages 285 microns long and 110 microns wide. After hatching, the $1^{\text {st }}$ instar, crawler that gets out from beneath the scale is also oblong yellowish white in color and measures 250 microns long and 125 microns wide. The female passes through two nymphal instars, while the male passes through four. For this reason, the main taxonomic characters of the different nymphal instars in both sexes were studied in details. In the adult stage, sex is clearly distinguished. The female becomes semicircular, elongated, and apterous, while the male is elongated and winged. P. blancgardi, like most insects of this group, protect itself with an armoured scale composed of exuviae and other secreted materials. After the last nymphal moult, the male usually emerges from beneath the scale, while the female remains motionless.

Key words: Scale insect; Date palm; Description; Homoptera; Diaspididae.

\title{
INTRODUCTION
}

P. blanchardi is a world wide major pest of palm tress, Phoenix dactylifera, and other Arecaceae, commonly known in Egypt due to the favorable climatic conditions for its development. The biology and ecology of the insect in the USA were studied by Ferris (1937) and by Benassy and Soria (1964) in Tunesia Chang and Tao (1963) gave a key distinguish this species it from two others of genus Parlatoria.

In Egypt, the insect was observed for the first time in 1937 (Hosny, 1943). Abdel-Fatah et al. (1978), and Ghabbour (1982) gave a brief description of the morphology and biology of the different stages of $P$. zizphus which attack citrus trees. Swailem et al. (1985) carried out some biological studies on P. zizyphus. Ghabbour and Mohammed (1996) showed some aspects of the bionomics and structures of diaspidid in Egypt. Granara and Claps (2003) mentioned that $P$. banchaordi has been recorded from date palm and other hosts belonging to the plant family Palmaceae. Thus the limited information in this respect ensured the importance of conducting further investigations to provide more details of structures. This will help to meet the ideas of several authors that some morphological structures in males in the superfamily coccoidea could be of taxomomic value.

\section{MATERIALS AND TECHNIQUES}

The experiments were carried out in the laboratories of the Faculty of Agriculture, University of Cairo at Giza during 2007. Highly infested leaves were selected from a date palm tree in this area and transferred to date palm seedlings transplanted in pots in the laboratory to start a new brood. By this

Fayoum J. Agric. Res. \& Dev., Vol.22, No.2, July, 2008 
artificial infestation the hatched crawlers usually settle on the leaves of seedlings. These nymphs were daily observed and all changes were recorded. Some of these insects at different stages of development were individually mounted on glass slides using Hoyer's medium for further examination under the microscope.

\section{RESULTS AND DISCUSSION}

A. Egg stage (Fig. 1,A) : The egg is oblong, whitish yellow turning to pinkish as it develops. It measures 285 microns long and $110 *$ microns wide. B. Nymphal stage:

First nymphal instar (Crawler) (Fig. 1,B): The crawlers leave the scale after hatching, move for 12-48hours before settling on leaf preferring the upper surface. It is oblong, yellowish white and measures 250 microns long and 125 microns wide. The crawler has 3 pairs of developed legs, a pair of 5segmented antennae and 2 simple eyes. Before secreting the new scale, it folds its appendages underneath its body. The secretion takes the shape of white filaments forming final shape of a white cover or cap. Which gradually increases in size reaching 320 microns long and 200 microns wide.

Second nymphal instar (Fig. 1,C):

\section{1- Female:}

Scale: After the first moult the scale darkens in colour and becomes more convex, measuring 460 microns long and 335 microns wide. The scale continues to enlarge reaching about 940 microns long and 620 microns wide at the end of the stage and the scale then appears in whitish colour with clean white anterior portion and a black area at the posterior end.

Body: the body turns to pinkish white and becomes oval with flat margins measuring 425 microns long and 315 microns wide. A pair of weak antennae and legs appear and sclerotized pygidium is distinct with two anterior scars.

\section{2- Male:}

Scale: Almost similar to that of the female with a white waxy area close to the posterior end. It measures 470 microns long and 340 microns wide and becomes more elongated at the end the stage.

Body: Also similar to that of the female except for two dark spots on the head. It measures 430 microns long and 330 microns wide.

\footnotetext{
* All mean measurements are approximated.

After the second moult, the female attains the adult stage, while the male passes through four instars before attaining the adult stage.

Third nymphal instar (prepupa) (male only):

Scale: flat white with a broad posterior end measuring 940 microns long and 350 microns wide.

Body: The colour turns to pink with a blush interacted appearance; and measures 730 microns long and 255 microns wide. The genital area becomes well developed (Fig. 1,D)

Fourth nymphal instars (Pupal stage ) (male only) (Fig.2,A):

Scale: White elongated parallel sided scale measuring 940 microns long and 350 microns wide.

Body : Whitish yellow and distinguished into three regions.

The head carries 2 pairs of antenna and two dark eyes, The thorax is divided into three segments bearing two wing buds and three pairs of legs. The abdomen is not clearly segmented having a concial stylus.
}

Fayoum J. Agric. Res. \& Dev., Vol.22, No.2, July, 2008 


\section{Adult stage:}

\section{1- Female:}

Scale: Large and light brown with a whitish waxy area at the end, measuring $1.2 \mathrm{~mm}$. long and $0.6 \mathrm{~mm}$. wide. At the final stage the scale attains a shieldy shape (Fig. 2,B1).

Body Whitish yellow turrining to pink, oblong, and measures 880 microns long and 545 microns wide. Two lobes appear on the head, one on each side, the pygidium is weakly sclerotized but a membranous body is generally obvious. (Fig. 2,C).

\section{2- Mall :}

Scale: No secretion is added after the second moult. The scale is very similar to that of the prepupa and pupa (Fig. 2,B2).

Body : Delicate and fusiform. Clearly distinguished into three body regions with yellowish brown color and measuring $0.82 \mathrm{~mm}$. long and $0.32 \mathrm{~mm}$. wide. The head with a pair of black compound eyes and a pair of segemented antennae; $0.4 \mathrm{~mm}$ long. The thorax is clearly divided into 3 segments with 3 pairs of well developed legs; a pair of transparent anterior wings; and a pairs of small halters. The abdomen is 9 segments, with genitalia at the posterior area; a penis pointed and surrounded by two caudal processes. (Fig.2,D).

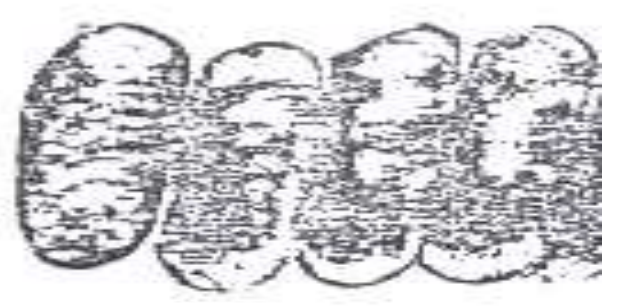

A

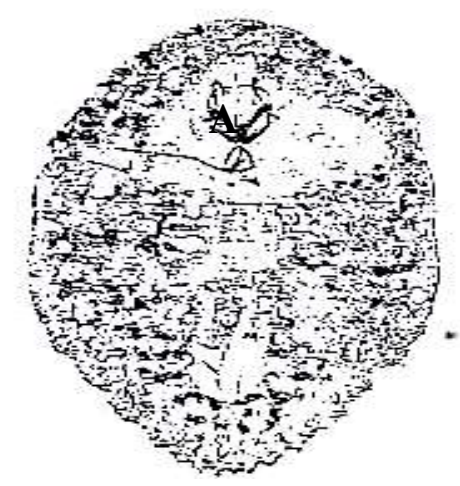

C

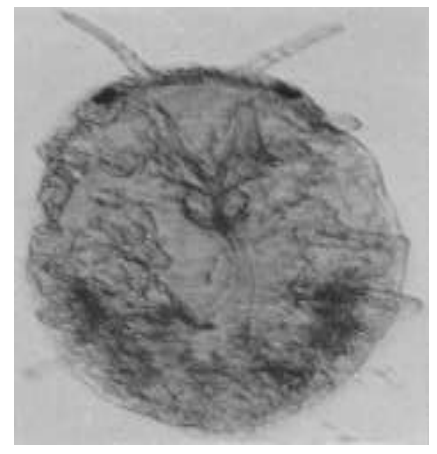

B

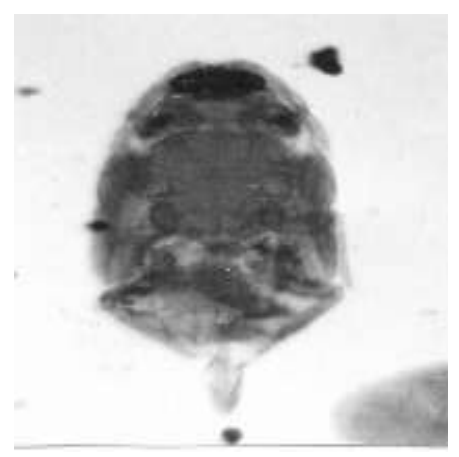

D

Fig. (1): P.blanchardi A- eggs B-first nymphal instar (Crawler) C- Second nymphal instar D- Third nymphal instar (Prepupal stage).

Fayoum J. Agric. Res. \& Dev., Vol.22, No.2, July, 2008 


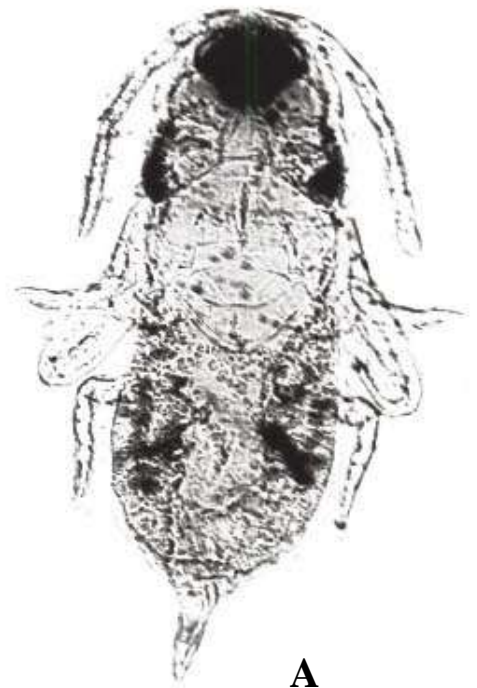

$\mathbf{A}$

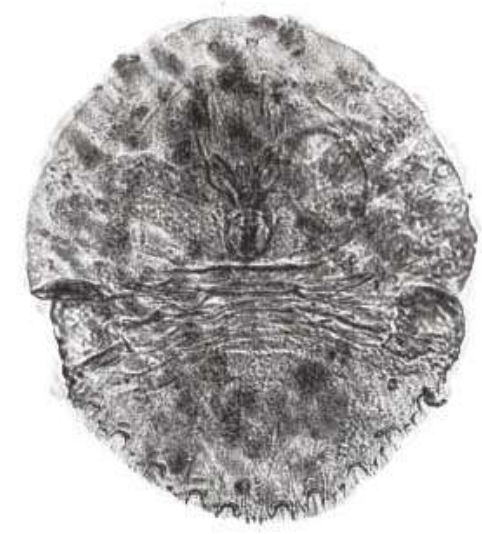

C

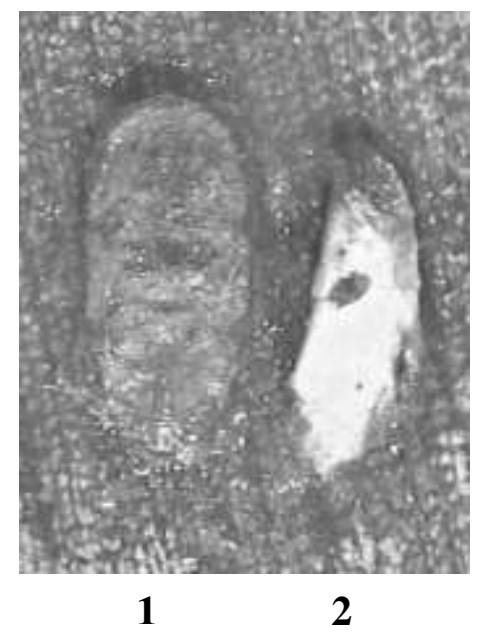

B

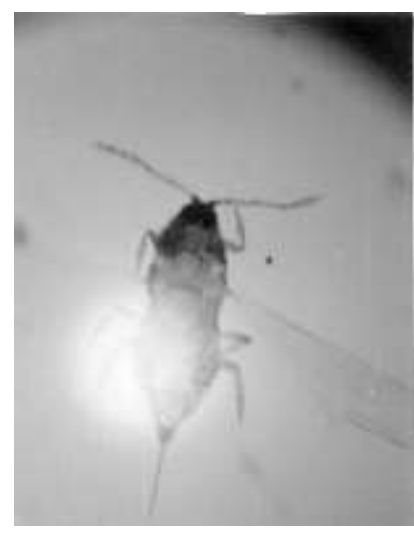

D

Fig. (2): P.blanchardi A-pupal stage, B- Adult scales 1- female 2- male, Cadult female, D- Adult male

\section{REFERENCES}

Abdel-Fattah, M.I.; A.M El- Minshawy and E.T Darwish (1978): Biology of the Zizyphus scale, Paralatoria zizyphus (Lucas) in Egypt. $4^{\text {th }}$ conf. Pest. Control, NRC, Cairo, (49-56).

Benassy; C. and F. Soria (1964): Ecological observation on the diapine coccids injurious to citrus in Tunesia. Ann. Inst. Natr. Resh. Agron. Tunesia, 37 (3): 193-221.

Chang Liang- Chuan; and Chia-Chu. Tao (1963): Black Parlatoria, Parlatoria zizyphus (Lucas). Agric , Res., 123(2): 34-47.

Ferris, G.F. (1973): Atlas of the scale insects of North America (Series III) 235 pp. Standford Univ. California, USA..

Fayoum J. Agric. Res. \& Dev., Vol.22, No.2, July, 2008 
DESCRIPTION OF THE DIFFERENT STAGES IN THE........ 119

Ghabbour, M.W. (1982): Morphological and Taxonomical studies on the immature stages of family Diaspididae in Egypt. M.Sc. thesis , Fac. of Agric., Ain Shams Univ., Cairo, Egypt.

Ghabbour, M.W. \& Mohammed (1996): The diaspidid of Egypt J. of Egypt. Germ. Soc. Zool . 21(E) 337-369.

Granara de Willink, M.C. and L. F Claps (2003): Scale insects present in Argentina, Neotropical Ento.32(4) : 625-637.

Hosny. S.M. (1943): Coccoidea new to Egypt with notes on some other species. Bull. Soc., Fouad 1er Ento, 23:113-123.

Swailem, S.M; M.M.El- Bolok and R.Y Abdel Aleem (1985): Biological studies on Parlatoria zizyphus (Lucas) (Homoptera, Diaspididae). Bull . Soc. Ent. Egypt., 67 (1): 301:317.

\section{وصف مورفولوجى لمختلف اطوار دورة حياة حشرة النخيل القشرية}

\section{Parlatoria blanchardi Targioni Tozzetti (Homoptera, Diaspididae)}$$
\text { ربيع يحيى عبد العليم }
$$$$
\text { قسم الحشرات الاقتصادية والمبيدات ـ كليةً الزراعة ـ جامعة القاهرة ـ الجيزة- مصر. }
$$

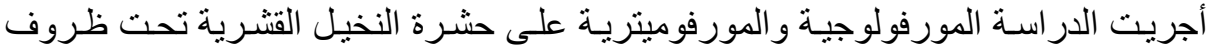

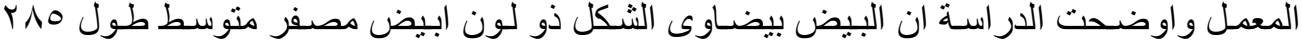

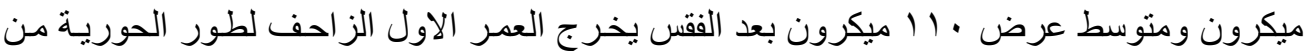

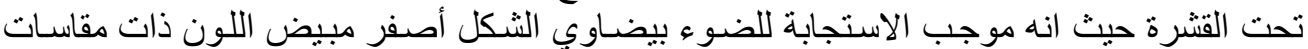

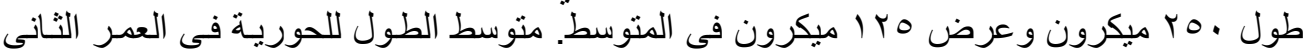

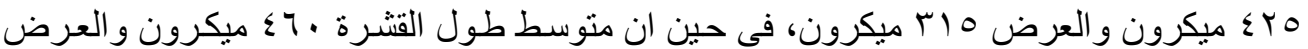

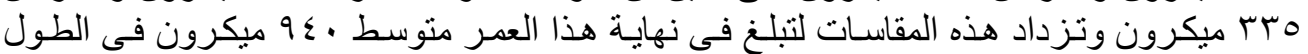

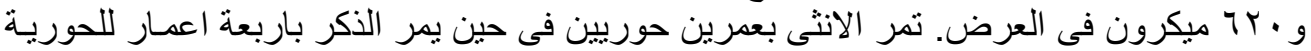

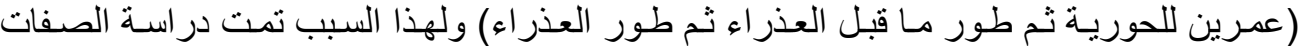

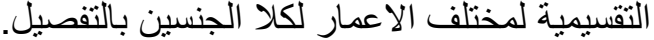

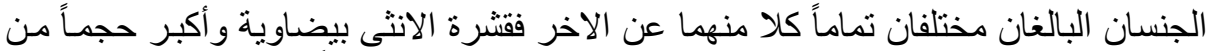

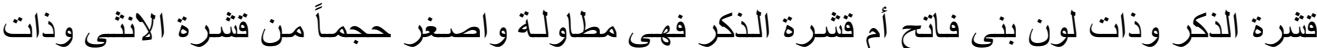

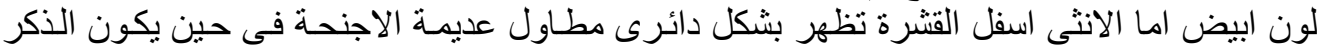

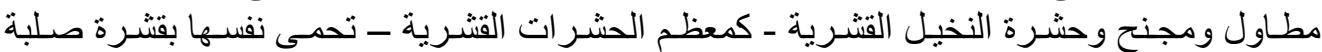$$
\text { مكونة من جلود الانسلاخ ومو اد افر ازية الفرية الخرى. }
$$

Fayoum J. Agric. Res. \& Dev., Vol.22, No.2, July, 2008 